\title{
PENGEMBANGAN E-MODUL BERBASIS TIGA LEVEL REPRESENTASI PADA MATERI KESETIMBANGAN KIMIA UNTUK SISWA SEKOLAH MENENGAH ATAS KELAS XI
}

\author{
Rabiatul Adawiyah ${ }^{1 *}$, Dwi Laksmiwati ${ }^{2}$, Supriadi $^{3}$, Mutiah $^{4}$ \\ $123{ }^{4}$ Program Studi Pendidikan Kimia FKIP Universitas Mataram. Jalan Majapahit No. 62 \\ Mataram, NTB 83112, Indonesia. \\ *Coressponding Author, Email: adawiyah201199@gmail.com
}

Received: 24 Juni 2021

Accepted: 30 November 2021 Published: 30 November 2021

doi: 10.29303/cep.v4i3.2744

\begin{abstract}
Abstrak
Penelitian ini bertujuan untuk mengetahui kelayakan, kepraktisan, dan keefektifan dari e-modul berbasis tiga level representasi pada materi kesetimbangan kimia di kelas XI yang sudah dikembangkan. Penelitian ini menggunakan metode R\&D (Research and Development) model 4D. Subjek penelitian ini terdiri dari dua dosen pendidikan kimia dan satu guru kimia SMA Negeri 1 Praya Timur sebagai penguji kelayakan e-modul berbasis tiga level representasi. Sedangkan uji coba skala kecil dilakukan pada siswa kelas XI SMAN 1 Praya Timur. Pengujian kelayakaan e-modul dari validator 1 diperoleh sebesar 76\% (kriteria cuku valid), validator 2 diperoleh sebesar $81 \%$ (kriteria cukup valid) dan validator 3 diperoleh sebesar $75 \%$ (kriteria cukup valid), penilaian uji keefektifan dari hasil belajar siswa diperoleh sebesar $80,8 \%$ (kriteria sangat efektif), dan penilaian kepraktisan e-modul dari angket respon siswa diperoleh sebesar 94\% (kriteria sangat praktis). Hasil penelitian ini menunjukkan bahwa e-modul berbasis tiga level representasi pada materi kesetimbangan kimia untuk kelas XI yang dikembangkan layak, praktis dan efektif meningkatkan hasil belajar siswa pada kondisi pademi Covid-19.

Kata Kunci: pengembangan, e-modul berbasis tiga level representasi, kesetimbangan kimia

\section{Development Of E-Modules Based On Three Levels Of Representation On Chemical Equality Materials For High School Students Of Class XI}

Abstract

This study aims to determine the feasibility, practicality, and effectiveness of the three-level representation-based e-module on chemical equilibrium topic in eleventh grade that has been developed. This study used the $4 D$ model $R \& D$ (Research and Development) method. The subjects of this study consisted of two chemistry education lecturers and one chemistry teacher at SMA Negeri 1 Praya Timur as the validators of e-modules based on three levels of representation. Meanwhile, a small-scale trial was conducted on eleventh grade students of SMAN 1 Praya Timur. The e-module feasibility test from the firstvalidator was obtained by $76 \%$ (sufficiently valid criteria), the secondvalidator obtained $81 \%$ (quite valid criteria) and the thirdvalidator obtained $75 \%$ (quite valid criteria), the effectiveness test assessment of student learning outcomes was obtained of $80.8 \%$ (very effective criteria), and the assessment of the practicality of e-modules from student response questionnaires obtained by $94 \%$ (very practical criteria). The results of this study indicate that the e-module based on three levels of representation on chemical equilibrium topic for eleventh grade which was developed is feasible, practical and effective in improving student learning outcomes during the Covid-19 pandemic.
\end{abstract}

Keywords: development, three-level representation-based e-module, chemical equilibrium 


\section{Chemistry Education Practice, 4 (3), 2021 - 263}

Adawiyah,Dwi Laksmiwati, Supriadi, Mutiah

\section{PENDAHULUAN}

Kimia merupakan ilmu yang mempelajari tentang sifat, struktur materi, komposisi materi, perubahan, dan energi yang menyertai perubahan materi (Purnama, 2016). Menurut Usu (2019) Pembelajaran merupakan salah satu proses dalam pendidikan. Salah satu tujuan dari pembelajaran ilmu kimia adalah memahami konsep, prinsip, hukum dan teori kimia serta saling keterkaitannya dan penerapannya untuk menyelesaikan masalah dalam kehidupan sehari-hari dan teknologi. Dari cakupan materi ilmu kimia, sebagian besar terdiri dari konsep-konsep yang bersifat abstrak. Hal ini sesuai dengan karakteristik ilmu kimia itu sendiri, yaitu: (1) bersifat abstrak, (2) penyederhanaan dari keadaan yang sebenarnya dan, (3) berurutan ketiga karakter inilah yang membuat ilmu kimia termasuk salah satu ilmu yang sulit untuk dipelajari oleh siswa. Salah satupenyebab ketidakmampuan siswa dalam memahami konsep adalah ketika siswa mengalami miskonsepsi. Miskonsepsi terjadi karena konsep kimia yang abstrak dan juga membutuhkan penalaran abstrak. Alasan lainnya karena konsep kimia umumnya mengharuskan siswa harus dapat menggunakan representasi dalam tiga tingkat yang berbeda: makroskopik, mikroskopik, dan simbolik (Johnstone,2000).

Menurut Gilbert dan Treagust (2009) Submikroskopik merupakan aspek menjelaskan secara kualitatif fenomena makroskopik yang terjadi pada skala molekuler menggunakan suatu model-model. Simbolik adalah bagian yang menghubungkan antara makroskopik dan submikroskopik menggunakan simbol- simbol. Keberhasilan siswa dalam belajar kimia ditunjukkan oleh kemampuannya untuk memecahkan masalah menggunakan tiga level representasi kimia, yaitu level representasi makroskopik, submikroskopik dan simbolik (Ariani, dkk., 2020). Karena itu, kemampuan representasi sangat penting dikembangkan dalam pembelajaran kimia (Supriadi, dkk., 2021).

Salah satu materi kimia yang sulit dipahami siswa adalah kesetimbangan kimia. Karena konsep kesetimbangan bersifat abstrak. Salah satu penyebab kesulitannya karena bahan ajar yang digunakan belum mengembangkan multipel reprsentasi kimia, sehingga tidak terintegrasi secara menyeluruh dalam pembelajaran. Beberapa siswa mengalami miskonsepsi dan kesulitan dalam memahami konsep kimia kesulitan siswa pada konsep kesetimbangan disebabkan karena kurangnya kemampuan menghubungkan tiga level representasi pada roses pembelajaran di Sekolah Menengah Atas (Supriadi.dkk, 2018).

$\begin{array}{lrr}\text { Pembelajaran } & \text { berbasis tiga level } \\ \text { representasi dapat dilakukan } & \text { dengan } \\ \text { memanfaatkan komputer.Menurut } & \text { Nurchali } \\ (2010) \text { pemanfaatan } & \text { komputer } & \text { dalam }\end{array}$ pembelajaran dapat memberikan pengalaman belajar yang banyak dan variatif, meningkatkan motivasi belajar serta mengembangkan keterampilan TIK (Teknologi Informasi dan Komunikasi) mahasiswa.Banyak keuntungan yang didapat melalui penerapan daring, dua diantaranya yang utama adalah meningkatkan efektivitas dan fleksibilitas pembelajaran. Mendukung pelaksanaan pembelajaran yang efektif dan fleksibel, dibutuhkan bahan ajar tambahan yang dapat memotivasi peserta didik dalam meningkatkan kegiatan belajar mandiri dalam menemukan konsep. Salah satunya adalah bahan ajar dalam bentuk modul. Modul disusun untuk membantu peserta didik mencapai tujuan yang dirumuskan secara khusus dan jelas. Bahan ajar dalam bentuk modul dapat dikombinasikan dengan bahan ajar multimedia interaktif dalam bentuk E-modul.

E-modul merupakan bahan ajar berupa modul yang ditampilkan dalam format elektronik yang diharapkan dapat meningkatkan minat dan motivasi belajar peserta didik. Hal ini dikarenakan e-modul melibatkan tampilan gambar, audio, video dan animasi (Suarsana dan Mahayuki, 2013). Selain itu e-modul dapat digunakan oleh peserta didik secara mandiri di sekolah maupun di rumah. E-modul sebagai bahan ajar memiliki karakteristik diantaranya: self instructional, self contained, stand alone, adaptif, user frendly, penggunaanfont,spasi dan tata letak yang konsisten, disampaikan melalui media elektronik berbasis komputer, memanfaatkan berbagai pilihan aplikasi softwere. Didesain dengan memperhatikan prinsip belajar dan pembelajaran (Direktorat Pembinaan SMA, 2017).

Berdasarkan hasil wawancara dengan salah satu guru kimia SMAN 1 Praya Timur "kendalanya dalam mengajar materi kimia termasuk di dalamnya materi kesetimbangan kimia adalah sebagian besar siswa memiliki motivasi belajar atau semangat belajar yang kurang dan siswa kebanyakan menganggap kimia itu sulit, kimia itu abstrak jika hanya dijelaskan di dalam kelas terlebih untuk materi kesetimbangan kimia, akan tetapi sebenarnya semangat belajar mereka sangat luar biasa jika belajarnya dengan menggunakan metode praktikum dan juga dengan media pembelajaran yang dibuat lebih 


\section{Chemistry Education Practice, 4 (3), 2021 - 264}

Adawiyah,Dwi Laksmiwati, Supriadi, Mutiah

menarik". Melihat hal ini peneliti berupaya melakukan pengembangan e-modul berbasis tiga level representasi pada materi kesetimbangan kimia untuk siswa sekolah menengah atas kelas XI.

\section{METODELOGI PENELITIAN}

Penelitian ini menggunakan model pengembangan R\&D (Research and Develompent) yang bertujuan untuk mengetahui kelayakan, kepraktisan dan kefektifan pada emodul berbasis tiga level representasi yang telah dikembangkan. Penelitian pengembangan R\&D (Research and Develompent) ini menggunakan model 4D (Define, Design, Development, dan Dessemination).E-Modul yang dikembangkan berupa sumber belajar elektronik yang dibuat menggunakan aplikasi flip builder. E-modul yang dikembangkan divalidasi oleh 2 dosen pendidikan kimia dan 1 guru mata pelajaran kimia SMA Negeri 1 Praya Timur. Uji coba skala kecil dilakukan pada kelas XI IPA 1 sebanyak 25 siswa. Teknik pengumpulan data yang digunakan yaitu: lembar validasi, angket respon siswa dan soal tes. Lembar validasi digunakan untuk pengujian kelayakan pada e-modul berbasis tiga level representasi, teknik angket respon siswa digunakan untuk pengujian kepraktisan dan teknik tes digunakan untuk pengujian kefektifan melalui post tes yang kemudian dibandingkan dengan nilai KKM mata pelajaran kimia di SMA Negeri 1 Praya Timur sebesar 75 untuk menentukan ketuntasan hasil bealajar siswa. Teknik analisis data untuk pengujian kelayakan menggunakan rumus:

Keterangan:

$$
\mathrm{P}=\frac{\sum \mathrm{X}}{\sum \mathrm{Xi}} \mathrm{X} 100 \%
$$

$\mathrm{P}=$ Persentasekelayakan

$\Sigma \mathrm{x}=$ Jumlah total skor masing-masing validator

$\Sigma x i=$ Jumlah total skor penilaiantertinggi.

Nilai yang diperoleh selanjutnya dibandingkan dengan kriteria pada tabel 1 .

Tabel 1. Kriteria Penilaian Produk

\begin{tabular}{ll}
\hline Presentase (\%) & Kriteria Evaluasi \\
\hline $86-100$ & $\begin{array}{l}\text { Sangat valid, dapat digunakan } \\
\text { tanpa revisi }\end{array}$ \\
Cukup valid, dapat digunakan \\
namun perlu revisi kecil \\
Kurang valid, disarankan \\
tidak dipergunakan karena \\
revisi besar \\
Tidak valid, tidak boleh \\
digunakan \\
\hline
\end{tabular}

(Akbar, 2013)

Teknik kepraktisan ditentukan berdasarkan banyaknya presentase siswa yang termasuk kategori praktis, teknik uji kepraktisan menggunkan rumus:

$$
\mathrm{TK}=\frac{\mathrm{SR}}{\mathrm{SM}} \mathrm{X} 100 \%
$$

Keterangan :

TK= Tingkat kepraktisan

$\mathrm{SR}=$ Skorrata-rata

$\mathrm{SM}=$ Skor maksimum

Tabel 2. Kategori Kepraktisan E-Modul pada Angket Respon Siswa

\begin{tabular}{cll}
\hline No. & Nilai & Kriteria \\
\hline 1 & $80 \%<\mathrm{x} \leq 100 \%$ & Sangat praktis \\
\hline 2 & $60 \%<\mathrm{x} \leq 80 \%$ & Praktis \\
\hline 3 & $40 \%<\mathrm{x} \leq 60 \%$ & Cukup praktis \\
\hline 4 & $20 \%<\mathrm{x} \leq 40 \%$ & Kurang praktis \\
\hline 5 & $0 \%<\mathrm{x} \leq 20 \%$ & Tidak praktis \\
\hline
\end{tabular}

(Riduwan, 2009)

Teknik uji kefektifan menggunakan nilai post tes yang kemudian dibandingkan dengan nilai KKM mata pelajaran kimia yaitu sebesar 75 untuk menentukan ketuntasan belajar siswa menggunakan rumus:

$X=\frac{\text { jumlah siswa tuntas }}{\text { jumlah total siswa }} X 100 \%$

Setelah itu dibandingkan dengan tabel kriteria efektivitas belajar.

Tabel 3. Kriteria Efektifitas Hasil Belajar

\begin{tabular}{ll}
\hline Presentase & Kriteria \\
\hline $\mathbf{8 0 \%}$ & Sangat efektif \\
$\mathbf{7 0 \% - 7 9 \%}$ & Efektif \\
$\mathbf{6 0 \% - 6 9 \%}$ & Cukup efektif \\
$\mathbf{5 0 \% - 5 9 \%}$ & Kurang efektif \\
$\mathbf{5 0 \%}$ & Tidak efektif \\
\hline
\end{tabular}

(Kubes, 2011)

\section{HASIL DAN PEMBAHASAN}

Penelitian ini merupakan penelitian pengembangan atau yang disebut dengan penelitian (R\&D) research and development. Tujuan dari penelitian ini adalah untuk menghasilkan suatu produk yang dalam hal ini berupa e-modul berbasis tiga level representasi. Dilakukan beberapa uji diantaranya uji coba yaitu uji kelayakan/validitas oleh validator, uji coba terbatas mengenai keefektifan melalui posttest untuk menentukan ketuntasan belajar siswa serta kepraktisan melalui angket respon 


\section{Chemistry Education Practice, 4 (3), 2021 - 265}

Adawiyah,Dwi Laksmiwati, Supriadi, Mutiah

siswa. Adapun pengembangan e-modul berbasis tiga level representasi dilakukan dalam beberapa langkah sebagai berikut:

\section{Pendefinisian (Define)}

Berdasarkan hasil observasi, diperoleh kesimpulan bahwa kendala dalam mengajar materi kimia sebagian besar para siswa memiliki semangat belajar yang rendah dan cenderung menganggap pelajaran kimia sulit dipahami, terlebih para siswa diharuskan belajar dari rumah atau tempat tinggal masing-masing. Hal tersebut berdampak pada kurangnya ketertarikan siswa dalam pembelajaran kimia khususnya pada materi kesetimbangan kimia. Sumber belajar yang kurang menarik mengakibatkan proses pembelajaran yang kurang menarik pula, membuat siswa menjadi kurang aktif dalam mengikuti proses pembelajaran, sehingga proses pembelajaran yang demikian akan menyulitkan siswa dalam memperolehpengetahuan.

Berdasarkan pada hasil tahapan pendefinisian tersebut, diperlukan suatu sumber belajar seperti e-modul berbasis tiga level representasi yang digunakan dalam kegiatan belajar mengajar. Dengan adanya pengembangan sumber belajar e-modul berbasis tiga level representasi dapat membuat proses belajar mengajar menjadi lebih menarik, membuat siswa menjadi lebih aktif, dimana siswa dapat memperoleh pengetahuannya sendiri melalui suatu sumber belajar yang dapat menjelaskan materi secara lebih mendalam dan kegiatan pembelajaran dalam tampilan yang menarik karena telah dilengkapi dengan gambar dan video, sehingga akan berdampak pada pengingkatan

hasil

belajarsiswa.(Laili.dkk.,2019)

\section{Perancangan (Design)}

Tahap perancangan dilakukan setelah memperoleh gambaran dari tahap pendefinisian. Dari tahap pendefinisian diperoleh bahwa perlu dikembangkannya suatu sumber belajar yang menarik seperti e-modul berbasis tiga level representasi pada materi kesetimbangan kimia. Perancangan isi e-modul berbasis tiga level representasi disusun berdasarkan KD (Kompetensi Dasar) dan indikator yang telah ditetapkan, dengan tampilan yang menarik dan dilengkapi dengan video yang menarik. Emodul yang dikembangkan sudah dilengkapi juga dengan link melalui aplikasi Whattsapp yang bisa diakses untuk pembelajaran dimana saja dan kapan saja saja terlebih pada kondisi pandemi Covid-19.
Tiga level representasi ini yakni representasi makroskopik, representasi submikroskopik, dan representasi simbolik (Jhonstone, 2007; Gilbert, 2008; Supriadi.dkk., 2018). Sebagai salah satu contoh pada e-modul kesetimbangan kimia berbasis tiga level representasi ini diberikan contoh pada sub bab materi pengaruh suhu pada kesetimbangan kimia, seperti gambar 1. Contoh representasi makroskopiknya dapat terlihat larutan $\mathrm{Co}\left(\mathrm{H}_{2} \mathrm{O}\right)$ yang berwarna ungu berubah menjadi larutan $\mathrm{CoCl}_{4}$ berwarna biru,karena berada dalam gelas erlenmeyer berisi es batu. Contoh representasi submikroskopik dapat dilihat pada gambar yang diberi tanda panah, terlihat pada gambar larutan $\mathrm{Co}\left(\mathrm{H}_{2} \mathrm{O}\right)$ dan larutan $\left(\mathrm{CoCl}_{4}\right)$ berupa molekulmolekul setelah dilakukan perbesaran gambar. Kemudian contoh pada representasi simboliknya adalah rumus kimia yakni $\mathrm{Co}\left(\mathrm{H}_{2} \mathrm{O}\right)$ dan $\mathrm{CoCl}_{4}$ serta persamaan reaksi yang terjadi.

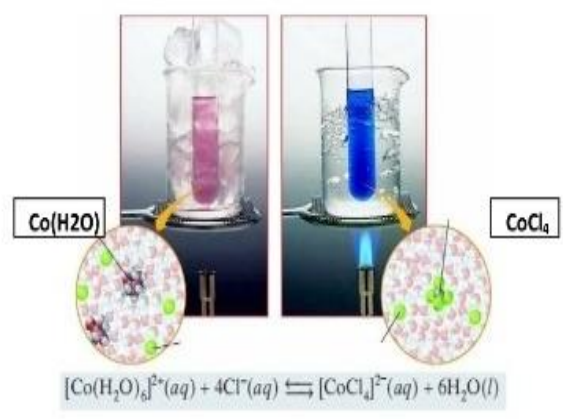

Gambar 1. Contoh materi kesetimbangan kimia berbasis tiga level representasi

Contoh e-modul berbasis tiga level representasi dapat dilihat pada gambar 2 .

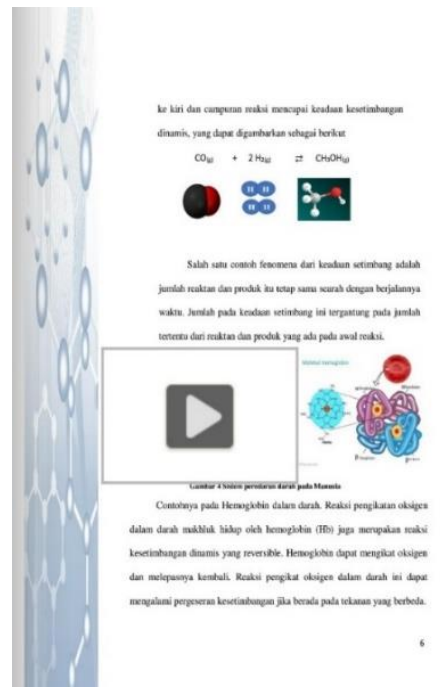

Gambar 2. Contoh materi yang dilengkapi video 
Pada gambar 2 terlihat e-modul berbasis tiga level representasi yang dikembangkan ini dalam format elektronik menggunakan aplikasi flipbuilder. Aplikasi ini mampu menampilkan tiga level representasi berupa gambar, video dan animasi.

\section{Pengembangan (Development)}

\section{Uji Coba Kelayakan E-Modul Berbasis Tiga Level Representasi}

Setelah didesain selanjutnya, penilaian e-modul dilaksanakan dengan menggunakan penilaian kelayakan instrumen oleh para ahli, yang terdiri atas komponen kegrafikan, komponen penyajian, komponen kelayakan, dan kebahasaan. Penilaian e-modul pada tahap ini dinyatakan lolos apabila setiap validator memberikan penilaian respon positif terhadap emodul yang dikembangkan. Penyajian Tabel 1 menunjukkan bahwa semua pakar telah memberikan penilaian positif terhadap e-modul yang dikembangkan dengan rerata presentase skor yang diperoleh dari validator I sebesar $71 \%$, dari validator II diperoleh rerata skor sebesar $81 \%$, dan validator III diperoleh rerata skor sebesar $75 \%$. Tahap ini menggunakan instrumen penilaian berupa e-modul yang telah dimodifikasi yang terdiri atas komponen kegrafikan, komponen penyajian, komponen kelayakan, dan kebahasaan. Penilaian instrumen tahap ini melibatkan 2 dosen FKIP Universitas Mataram dan 1 guru mata pelajaran kimia sebagai validator masing-masing komponen. Uji kelayakan e-modul berbasis tiga level representasi ini juga mendapat masukan dari validator berupa : perbaikan font yang tidak seragam, tata penomoran yang belum sesuai dan warna tulisan keterangan gambar yang harus diubah menjadi warna gelap. Peneliti sudah melakukan perbaikan font, sudah melakukan perbaikan penomoran-penomoran dan sudah melakukan perbaikan pada warna keterangan gambar dari terang menjadi gelap.

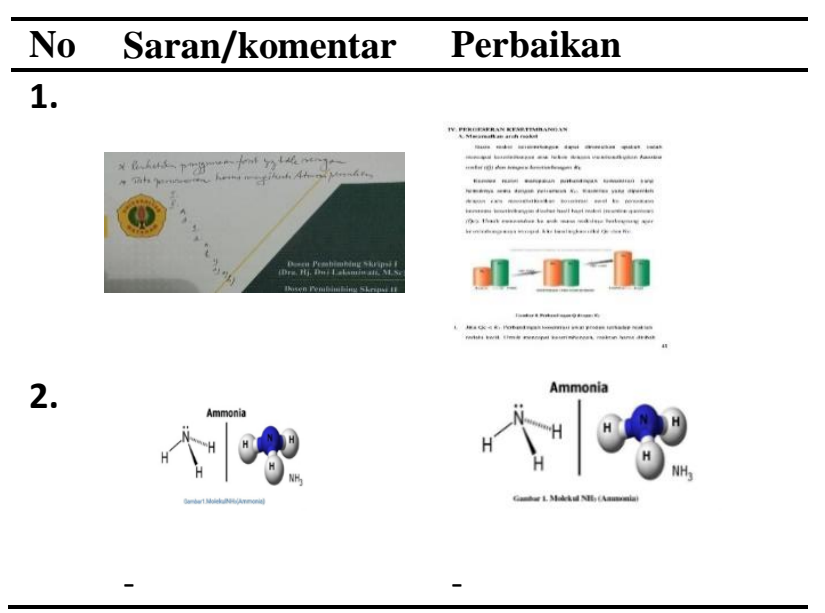

Gambar 3. Tabel revisi e-modul dari validator

\section{Keefektifan E-Modul Berbasis Tiga Level Representasi}

Penelitian ini selain untuk mengetahui kelayakan e-modul yang dikembangkan juga dimaksudkan untuk mengetahui keefektifan emodul berbasis tiga level representasi pada materi kesetimbangan kimia untuk kelas XI SMA. Uji skala kecil dilaksanakan di kelas XI IPA 1 SMAN 1 Praya Timur dengan jumlah siswa sebanyak 25 siswa. Proses pembelajaran diawali dengan siswa diberikan link melalui WhatsApp untuk mengakses e-modul berbasis tiga level representasi sebagai sumber belajar pada materi kesetimbangan kimia. Pada akhir pembelajaran materi kesetimbangan kimia, siswa mengerjakan soal posttest yang terdiri dari 5 soal pilihan ganda untuk mengetahui pencapaian hasil belajar setelah dilaksanakan pembelajaran menggunakan e-modul berbasis tiga level representasi. Nilai posttest ini akan dikomulasikan dengan perbandingan nilai KKM yang sudah ditentukan. Hasil penilaian tes dilakukan dengan menghitung siswa yang nilainya tuntas dalam pembelajaran kemudian dikomulasikan ke dalam persentase untuk mengetahui peningkatan pembelajaran menggunakan $\mathrm{e}$-modul berbasis tiga level representasi.

Berdasarkan analisis menggunakan hitungan persentase, hasil penelitian menunjukkan adanya peningkatan secara keseluruhan pemahaman konsep siswa antara posttest dengan perbandingan nilai KKM, yaitu perbedaan hasil tes siswa sesudah diterapkannya pembelajaran dengan e-modul berbasis tiga level representasi yang dikembangkan. Hasil nilai posttest mendapatkan nilai rata-rata $80,8 \%$. Berdasarkan analisis peningkatan skor rata-rata post test setelah diterapkan pembelajaran 


\section{Chemistry Education Practice, 4 (3), 2021 - 267}

Adawiyah,Dwi Laksmiwati, Supriadi, Mutiah

menggunakan e-modul berbasis tiga level representasi dikategori efektif. Penilaian pemahaman konsep siswa pada uji pelaksanaan skala kecil pembelajaran menggunakan e-modul berbasis tiga level representasi memperoleh nilai tertinggi yang dicapai siswa adalah 93,33 , sedangkan nilai terendah 66,67, dan nilai akhir rata-rata kelas adalah 83,72. KKM mata pelajaran kimia di SMAN 1 Praya Timur yaitu 75. Hasil perhitungan ketuntasan belajar diketahui bahwa siswa yang tidak tuntas sebanyak 4 dari 25 siswa. Sehingga didapatkan presentase ketuntasan belajar siswa sebesar 80,8 $\%$ yaitu berada dalam kritria sangat efektif.

Berdasarkan tabel hasil belajar menunjukan pemahaman siswa terhadap materi mencapai $80,8 \%$. Hasil penilaian tersebut menunjukkan bahwa siswa yang tuntas belajar sebanyak 21 siswa dan yang tidak tuntas sebanyak 4 siswa. Hal ini menunjukkan pembelajaran menggunakan e-modul berbasis tiga level representasi yang dikembangkan memperoleh krikteria sangat efektif, karena siswa tertarik dan termotivasi dalam belajar.

\section{Kepraktisan E-Modul Berbasis Tiga Level Representasi}

\section{Angket Tanggapan/ResponSiswa}

Selain penilaian kelayakan dengan menggunakan instrumen penilaian yang dinilai oleh pakar, kelayakan e-modul juga dilihat dari hasil angket tanggapan siswa. E-modul berbasis tiga level representasi berdasarkan penilaian pakar dan dinyatakan layak digunakan dilapangan, selanjutnya dilakukan uji coba dalam skala kecil dengan jumlah responden 25 siswa. Pada tahap uji coba skala kecil, siswa diberikan angket untuk menilai tampilan emodul berbasis tiga level representasi. Hasil rekapitulasi angket yang diberikan kepada siswa memperoleh rata-rata presentase $94 \%$ dengan kriteria sangat praktis. Siswa beranggapan bahwa e-modul berbasis tiga level representasi dapat menarik minat mereka untuk mempelajari e-modul. Siswa menilai bahasa yang digunakan mudah dipahami, e-modul yang dikembangkan juga lebih berwarna dan dilengkapi gambar dan video yang menarik berhubungan dengan materi kesetimbangan kimia. Para siswa setuju e-modul yang dikembangkan membuat siswa tertarik untuk mempelajari e-modul berbasis tiga level representasi.

Berdasarkan hasil analisis angket tanggapan/respon siswa maka diperoleh bahwa e-modul berbasis tiga level representasi mendapat respon positif dari siswa. Hal ini menyatakan bahwa e-modul yang dikembangkan layak untuk diterapkan dalam pembelajaran dengan memperoleh kriteria sangat baik yaitu 94\% untuk tanggapan siswa.

\section{SIMPULAN}

E-Modul berbasis tiga level representasi telah dikembangkan dengan model 4D yaitu terdiri dari tahap Define (Pendefinisian), Design (Perancangan), dan Development (Pengembangan) tanpa melakukan tahapan Dissemination (Desimasi). Berdasarkan hasil penelitian dan kajian produk e-modul berbasis tiga level representasi, dapat disimpulkan bahwa: (1) Hasil penilaian para pakar terhadap e-modul berbasis tiga level representasi pada materi kesetimbangan kimia untuk kelas XI SMA diperoleh kriteria cukup valid dan layak digunakan untuk pembelajaran kesetimbangan kimia. (2) E-modul berbasis tiga level representasi pada materi kesetimbangan kimia untuk kelas XI SMA yang dikembangkan sangat praktis dilihat dari tanggapan siswa terhadap emodul berbasis tiga level representasi yang dikembangkan dalam uji coba skala kecil.

\section{DAFTAR PUSTAKA}

Akbar. 2013. Instrumen Perangkat Pembelajaran. Bandung: Rosda.

Ariani, S., Effendy, E., \& Suharti, S. (2020). Model Mental Mahasiswa Pada Fenomena Penghilangan Karat Melalui Elektrolisis. Chemistry Education Practice, 3(2), 55-62.

Arikunto. S. 2013. Prosedur Penelitian Suatu Pendekatan Praktik (Edisi Revisi). Jakarta: Rineka Cipta.

Direktorat Pembinaan Sekolah Menengah Atas. 2017. Panduan Penilaian oleh Pendidik dan Satuan Pendidikan SMA. Jakarta: KementerianPendidikan dan Kebudayaan.

Elaine, B. J.2007. Contextual Teaching and Learning; Menjadikan Kegiatan BelajarMengajar Mengasyikan dan Bermakna. Bandung : MLC.

Gilbert, J. K., \& Treagust, D. F. Towards a Coherent Model for Macro, Submicro and Symbolic Representations in Chemical Education. Models and Modeling in Science Education, 333.

Kasmir. 2003. Bank dan Lembaga Keuangan Lainnya. Jakarta: PT Raja Grafindo Persada.

Kubes, I. I. (2011). Efektivitas instrumen evaluasi hasil belajar menggunakan media elektrik quiz pada materi pokok larutan 


\section{Chemistry Education Practice, 4 (3), 2021 - 268}

Adawiyah,Dwi Laksmiwati, Supriadi, Mutiah

buffer kelas XI MAN 1 Salatiga (Doctoral dissertation, IAIN Walisongo).

Laili, I. (2019). Efektivitas Pengembangan EModul Project Based Learning pada Mata Pelajaran Instalasi Motor Listrik. Jurnal Imiah Pendidikan Dan Pembelajaran, 3(3), 306-315.

Nadeak, B., Parulian, A., Pristiwanto, P., \& Siregar, S. R. (2016). Perancangan Aplikasi Pembelajaran Internet dengan Menggunakan Metode Computer Based Instruction. JURIKOM (Jurnal Riset Komputer), 3(4).

Nurchaili, N. (2010). Membentuk Karakter Siswa melalui Keteladanan Guru.

Jurnal Pendidikan dan Kebudayaan, 16(9), 233-244.

Puji, K. M., Gulö, F., \& Ibrahim, A. R. (2014). Pengembangan multimedia interaktif untuk pembelajaran bentuk molekul di SMA. Jurnal Penelitian Pendidikan Kimia, 1(1), 59-65.

Purnama, R. D., Mawardi, M., \& Fadhilah, R. (2016). Analisis Kesulitan Belajar Kimia pada Materi Larutan Penyangga Siswa Kelas XI IPA 1 MAN 2 Pontianak. $A R$ RAZI Jurnal Ilmiah, 4(2).

Richey, R. C., \& Klein, J. D. (2013). Design and development research. Handbook of
Research on Educational Communication and Technology, 141-150.

Suarsana, I. M. (2013). Pengembangan e-modul berorientasi pemecahan masalah untuk meningkatkan keterampilan berpikir kritis mahasiswa. JPI (Jurnal Pendidikan Indonesia), 2(2).

Supriadi, S., Ibnu, S., \& Yahmin, Y. (2018). Analisis model mental mahasiswa pendidikan kimia dalam memahami berbagai jenis reaksi kimia. Jurnal Pijar MIPA, 13(1), 1-5.

Supriadi, S., Wildan, W., Hakim, A., Savalas, L. T., \& Haris, M. (2021). Model Mental dan Kemampuan Spasial Mahasiswa Tahun Pertama dan Ketiga Pendidikan Kimia di Universitas Mataram. Jurnal Pijar Mipa, 16(3), 282-287.

Thiagarajan, S. (1974). Instructional development for training teachers of exceptional children: A sourcebook.

Usu, N., Rahmanpiu dan Marhadi, M. A.(2019).Analisis Miskonsepsi Pada Materi Kesetimbangan Kimia Menggunakan Tes Diagnotik Two Tier Multiple Choice. Jurnal Pendidikan Kimia FKIP Universitas Halu Oleo.(4)3,226. 